\title{
High molecular polymorphism of the hypervariable region in the VP2 gene of Aleutian mink disease virus
}

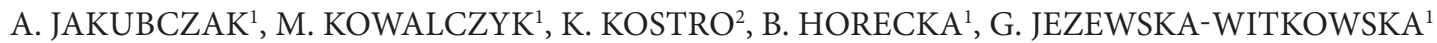

\begin{abstract}
${ }^{1}$ Department of Biological Basis of Animal Production, University of Life Sciences in Lublin, Akademicka St. 13, 20-950 Lublin, Poland; ${ }^{2}$ Department of Epizootiology and Clinic of Infectious Diseases, University of Life Sciences in Lublin, Gleboka St. 30, 20-950 Lublin, Poland
\end{abstract}

Received January 28, 2016; revised May 10, 2016; accepted October 10, 2016

\begin{abstract}
Summary. - Parvoviruses exhibit extreme genetic plasticity. The VP2 protein, containing a hypervariable region, is of particular importance. A single nucleotide change in this part of the genome and its effect on the amino acid sequence may significantly affect the range of infected hosts, tropism for specific tissues, or virulence. The high polymorphism in the hypervariable region can be exploited for phylogenetic analysis. The aim of this study was to analyze the polymorphism of the VP2 hypervariable region in isolates of the Aleutian mink disease virus (AMDV) infecting Polish mink farms and to determine the phylogenetic relationships between the Polish isolates and genetic variants of the pathogen occurring in other countries. The study compares farms from two regions of Poland. The isolates contained five changes in the amino acid sequence, which had not previously been recorded in the NCBI database. There were 21 changes noted between the genotypes obtained and the sequence of the reference strain [GenBank NC_001662.1], of which 8 were in the hypervariable region. The isolates identified in our study exhibit a high degree of similarity within the farms, but between farms there is considerable variation in the amino acid sequence of the VP2 protein fragment. Because variants characteristic for farms were obtained, it will be possible to trace the movement of the virus between farms, and in the longer term to use the characteristic sequences as a marker of the origin of infected animals.
\end{abstract}

Keywords: Aleutian mink disease virus; VP2 protein; polymorphism; phylogenetics

\section{Introduction}

Poland is one of the most important producers of mink furs in the world. In contrast to other important producers (Finland, Denmark, Canada, Sweden, or China), only a few studies have been conducted on the prevalence and diversity of Aleutian disease virus in Poland (Reichert and Kostro, 2014b), which is an important factor causing economic losses. We present the first results of research on genetic polymorphism in a fragment of the VP2 protein sequence containing a hypervariable region in isolates appearing in Poland.

E-mail: andrzej.jakubczak@up.lublin.pl; phone: +48-81-4456992. Abbreviations: $\mathrm{AMDV}=$ Aleutian mink disease virus; $\mathrm{CIEP}=$ counter-immuno-electrophoresis; CPV-2 = canine parvovirus type 2; UPGMA = unweighted pair group method with arithmetic mean
Aleutian disease is currently a serious problem causing substantial economic losses on mink farms. Low production on farms infected with AMDV is the consequence of frequent abortion, low fecundity, a high kit mortality rate during the first days after birth, and fairly numerous deaths in minks at the age of a few months as result of infection. The main symptoms are anemia, black tarry stool, lethargy, weight loss, seizures, enlarged spleen and hind leg weakness (Reichert and Kostro, 2014a; Persson et al., 2015). AMDV exhibits strong lymphoid tissue tropism, and its main target cells are B and T cells. In adult mink, a chronic form of the disease associated with persistent infection develops, causing continual, excessive stimulation of the humoral immune response, leading to plasmacytosis and gammopathy. The course of AMDV infections varies depending on the virulence of the infecting strain, the age of the mink, the functional state of the immune system and the animal's genotype 
(Knuuttila et al., 2009b). On Polish farms on which AMDV is endemic, the course of infections in adult farmed mink is usually subclinical - minks infected with AMDV may appear clinically healthy but often have poor reproduction (Reichert and Kostro, 2014a,b).

The disease is induced by the non-enveloped parvovirus AMDV (Aleutian mink disease virus) belonging to the genus Amdovirus and the family Parvoviridae (Dam-Tuxen et al., 2014). The genetic material of AMDV is single-strand of DNA about 5,000 base pairs in length (Huang et al., 2014). The genome of the virus contains genes encoding three non-structural proteins (NS1, NS2 and NS3) involved in the replication process and in regulating transcription of the virus's genetic material (Reichert and Kostro, 2014b). The virus also possesses two structural proteins, VP1 and VP2, of which VP2 plays a particularly important role; it exhibits a high degree of variation between strains and thus largely determines the virulence of the infecting strain (Li et al., 2012; Sang et al., 2012; Huang et al., 2014; Wang et al., 2014; Leimann et al., 2015). Different isolates of the AMDV virus exhibit different pathogenicity, from the non-pathogenic strain AMDV-G, to strains that are highly pathogenic for the Aleutian variety of mink, to highly virulent strains such as the Utah strain, characterized by a high mortality rate in all varieties of mink (Oie et al., 1996, 2006). Differences in pathogenicity are associated with the capsid protein sequence. The sequence encoding the VP2 capsid protein contains a hypervariable region. Mutations in the nucleotide sequence encoding the capsid protein (VP1 and VP2) determine the pathogenicity (Pennick et al., 2005). McKenna et al. (1999) confirmed that this localization may play an important role in tissue tropism and pathogenicity as well as in antigenic properties, as a strain-specific epitope may be situated in this region. Strain-specific amino acids present in this part of the sequence make it possible to distinguish different strains of AMDV (ADV-G strain, ADV-Utah I strain, ADV-K strain) (Gottschalck et al., 1991; Li et al., 2012).

To diagnose Aleutian disease, the counter-immunoelectrophoresis (CIEP) method is routinely used, and more recently also ELISA assays aimed at detecting the presence of specific antibodies (Knuuttila et al., 2009a; Andersson and Wallgren, 2013; Dam-Tuxen et al., 2014). However, in the case of strains inducing non-persistent infections, the level of antibodies in infected animals is low and often cannot be detected by serological methods (Andersson and Wallgren, 2013). Molecular methods are oriented at detection of viral genetic material, whereas serological methods are limited to antibodies. Methods of molecular biology making it possible not only to confirm or rule out infections, but also, owing to bioinformatics tools and databases, to accurately identify the strain and even trace the source of the infection, may constitute a significant advance in diagnostics.
The problem of AMDV infections calls for research aimed at more precise characterization of strains of this virus circulating on breeding farms in Poland. Therefore, the aim of this study is the molecular characterization of AMDV isolates occurring on Polish mink farms and determination of their phylogenetic relationships with strains isolated abroad.

\section{Materials and Methods}

Sample collection. The study was carried out in the years 2013-2014 on two mink breeding farms with foundation stock numbering 2,000 and 10,000 females, respectively. The sanitary conditions on the farms were assessed as satisfactory. For the last three breeding seasons, persistent subclinical AMDV infections, confirmed by CIEP, have been noted in about $60 \%$ of the foundation stock of the farms. Moreover, there has been a fairly high percentage of unmated females (9-10\%), females that mated normally but failed to whelp (10-12\%), and aborting females (5-7\%), as well as a high newborn mortality rate and a low average number of weaned kits (2.4 per female). The subjects of the analysis were 16 one-year-old minks of the brown variety. In selecting the animals for the study, we took into consideration minks, in which the presence of specific anti-AMDV antibodies had been detected by CIEP during specific diagnosis conducted at the beginning of 2014. The biological material for serological diagnosis of AMDV consisted of blood samples collected from live animals into capillary tubes by toenail clipping. The study was performed according to statutory bioethical standards and approved by the Local Ethics Commission of the University of Life Sciences in Lublin, approval no. 83/2009. The samples were tested by CIEP. Postmortem material for genotyping of AMDV consisted of samples of internal organs (spleen and retropharyngeal lymph nodes) collected from the same animals during the planned slaughter period (the first half of December). A total of 16 individuals were chosen for the analysis -6 from farm A, situated in north-eastern Poland (Nos. 1-6), and 10 from farm B, located in western Poland (Nos. 7-16).

DNA isolation. DNA was extracted from the spleen, which was cut into small pieces of $5 \mathrm{mg}$. Tissues were lysed using TissueLyser II (QIAGEN) for $5 \mathrm{~min}$ at a frequency of $30 \mathrm{1} / \mathrm{sec}$, with $200 \mu$ of ATL buffer added to the sample. DNA was isolated with a DNeasy Blood and Tissue kit (QIAGEN) according to the manufacturer's protocol.

PCR amplification and sequencing. A fragment of the VP2 sequence was amplified using the forward primer 5'-TCT AGAAGCAACGCTTGGGGTGTATG-3' and the reverse primer 5'-GTTGTGTCACTCCACTGTCT-3' according to Costello et al. (1999). The reactions ( $25 \mu \mathrm{l}$ total volume) contained $2 \mu \mathrm{LNA}$ and 1.43 U Taq polymerase (AmpliTaq Gold 360 DNA Polymerase, Applied Biosystems) in the manufacturer's buffer, adjusted to a final concentration of $2 \mathrm{mmol} / \mathrm{l} \mathrm{MgCl} ; 0.8 \mathrm{mmol} / \mathrm{l}$ of each dNTP; and $1.2 \mathrm{mmol} / \mathrm{l}$ of each primer. PCR cycling conditions were $95^{\circ} \mathrm{C}$ for $10 \mathrm{~min}, 35 \mathrm{cycles}$ of $95^{\circ} \mathrm{C}$ for $30 \mathrm{sec}, 58^{\circ} \mathrm{C}$ for $60 \mathrm{sec}, 72^{\circ} \mathrm{C}$ for 60 
sec and $72^{\circ} \mathrm{C}$ for $10 \mathrm{~min}$ (Labcycler, SensoQuest). To confirm the presence of PCR products, gel electrophoresis was carried out using $2 \%$ agarose gel with ethidium bromide (EtBr). The PCR product was purified using an ExoSAP-IT kit (Affymetrix). Sequencing PCR was carried out with a BigDye ${ }^{\circledR}$ Terminator v3.1 Cycle Sequencing Kit (Applied Biosystems). PCR products were purified using a DyeEx Spin Kit (Qiagen) in a QIAcube and sequenced using a 3100 Genetic Analyzer (Applied Biosystems).

Bioinformatic processing. The sequences were processed using DNA Baser [DNA Baser Sequence Assembler v4.x (2014), Heracle BioSoft]. Sequences of 611 nucleotides were obtained. Nucleotide sequences were translated to amino acid sequences using MEGA 6 software (yielding a fragment of 203 amino acids). All sequences were deposited in GenBank [GenBank: KR080136-KR080144]. NC_001662.1 from GenBank was selected as a reference sequence, as in a previous study by Jahns et al. (2010). The choice of this sequence shows the great variability among AMDV isolates. Assembly, alignment and comparison of nucleotide and amino acid sequences were performed using MEGA 6 software. Tree topology was similar for different methods of analysis, but the model obtained by UPGMA seemed to most reliably reflect the evolution of AMDV and the phylogenetic relationships between strains. Therefore, a phylogenetic tree was prepared by the UPGMA method using MEGA 6 software. Visualization of the tree was prepared using FigTree 1.4.2 software.

\section{Results}

The viral isolates from farm B represented 5 genotypes, with genotype I present in 2 individuals, genotype III in 5, and the remaining genotypes (II, IV and V) in one animal each (Table 1). Four genetic variants were noted in the isolates from farm A; variants I-III were observed in single cases, while genotype IV occurred most frequently ( 3 individuals). Comparison of the results obtained with resources available in the NCBI database revealed four changes that were not present in the sequences that had previously been deposited. In the case of individuals from farm $\mathrm{B}$, an isoleucine to leucine substitution was noted at position 325 (I325L), an asparagine to histidine substitution at position $332(\mathrm{~N} 332 \mathrm{H}$ in each of the isolates from farm $\mathrm{B})$, and a glutamic acid to lysine substitution at position 349 (E349K). In one viral isolate from farm A there were two substitutions (D241I and E349K), which were not present in the sequences deposited in the available bioinformatics databases. There were 21 differences observed between the genotypes obtained and the reference strain sequence [GenBank: NC_001662.1] - AMDV-G, of which 8 were in the hypervariable region. For the isolates from farm $B$, substitutions F172Y, L324I, Q328E and N332H were characteristic, as well as a threonine deletion at position 235 . In the case of the samples from farm A, the only change occurring in every isolate and enabling differentiation from the isolates from farm B was I325V.

The hypervariable nature of the amino acid sequence enhances the resolution of the phylogenetic analysis. We obtained similar tree typology to that presented by Wang et al. (2014). The isolates from Poland belong to two branches of the same clade (group Ia and Ib). Analysis of the cladogram presented in Fig. 1 shows that the isolates identified in our study have a high degree of similarity within each farm, whereas between farms A and B there is substantial variation in the amino acid sequence of the VP2 fragment. Different isolates on one farm have previously been noted by Olofsson et al. (1999). Moreover, one individual can be infected by several different isolates; cases of multiple infections were described by Gottschalck et al. (1991).

\section{Discussion}

The VP2 protein seems to be crucial to the properties and pathogenicity of AMDV. The significance of capsid proteins in the pathogenesis of infection lies in the fact that they determine susceptibility to the neutralizing properties of antibodies, tropism for particular tissues and organs, and adaptation to a particular species (Bloom et al., 2001; Li et al., 2012). Battilani et al. (2006) confirmed a high degree of variation in the sequence encoding the VP2 coat protein in parvoviruses infecting dogs and cats. Even minor changes in the nucleotide and amino acid sequence can have a significant effect on biological characteristics and pathogenicity (Majer-Dziedzic et al., 2011).

Canine parvovirus type $2(\mathrm{CPV}-2)$ is well-known representative of parvoviruses. Its origin is strongly linked to changes in the capsid protein sequence. The virus is believed to be derived from Feline panleukopenia virus (FPV), with differences between them occurring only in the VP2 sequence (K93N and D323N) (Shackelton et al., 2005). According to Jahns et al. (2010), changes in the sequence of two amino acids can determine the affinity of the virus for the central nervous system. In the case of CPV-2, a change in the amino acid sequence leads to a broadening of the host spectrum to include cats (Battilani et al., 2006), raccoon dogs (Oie et al., 1996) and foxes (Sánchez-Migallón Guzmán et al., 2008).

An area that is particularly susceptible to changes is the fragment between amino acid positions 230 and 244, known as the hypervariable region. This is a 'hotspot' in the viral genome and therefore an ideal site for phylogenetic and evolutionary analyses.

The hypervariable region is considered to be especially significant in differentiation of strains and analysis of their origin (Jahns et al., 2010). Wang et al. (2014) observed that three mutations were exclusive to Chinese samples, and all of 
Table 1. Amino acid sequence polymorphism of the VP2 fragment of the AMDV

\begin{tabular}{|c|c|c|c|c|c|c|c|c|c|c|c|c|c|c|c|c|c|c|c|c|c|c|}
\hline \multirow{2}{*}{ Accession number } & \multirow{2}{*}{$\begin{array}{c}\text { Country of } \\
\text { origin }\end{array}$} & \multicolumn{21}{|c|}{ Amino acid position } \\
\hline & & 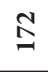 & 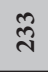 & तె & $\stackrel{\sim}{\tilde{N}}$ & $\hat{\tilde{N}}$ & ते & $\underset{\sim}{\mathbb{7}}$ & $\underset{\sim}{\mathbb{7}}$ & $\stackrel{\mathscr{Z}}{\mathrm{H}}$ & $\stackrel{\infty}{\sim}$ & ఫ్లి & ठ্े & $\bar{m}$ & $\frac{\infty}{m}$ & $\stackrel{\vec{m}}{ }$ & तె & กี & స్ & లై & ले & in \\
\hline NC_001662.1 & USA & $\mathrm{F}$ & $\mathrm{V}$ & $\mathrm{A}$ & $\mathrm{T}$ & $\mathrm{T}$ & $\mathrm{T}$ & $\mathrm{D}$ & $\mathrm{A}$ & $\mathrm{V}$ & $\mathrm{N}$ & $\mathrm{K}$ & $\mathrm{T}$ & $\mathrm{T}$ & $\mathrm{K}$ & $\mathrm{E}$ & $\mathrm{L}$ & $\mathrm{I}$ & $\mathrm{Q}$ & $\mathrm{N}$ & $\mathrm{E}$ & I \\
\hline KR080140 & farm B_1 & $\mathrm{Y}$ & $\mathrm{T}$ & G & - & $\mathrm{Q}$ & $\mathrm{E}$ & $\mathrm{T}$ & G & $\mathrm{T}$ & $\mathrm{K}$ & $\mathrm{T}$ & $\mathrm{S}$ & . & $\mathrm{L}$ & $\mathrm{Q}$ & $\mathrm{I}$ & . & $\mathrm{E}$ & $\mathbf{H}$ & . & $\mathrm{V}$ \\
\hline KR080141 & farm B_2 & $\mathrm{Y}$ & $\mathrm{T}$ & G & - & $\mathrm{Q}$ & $\mathrm{E}$ & $\mathrm{T}$ & G & $\mathrm{T}$ & $\mathrm{K}$ & $\mathrm{T}$ & $\mathrm{S}$ & . & $\mathrm{L}$ & . & $\mathrm{I}$ & . & $\mathrm{E}$ & $\mathbf{H}$ & $\mathbf{K}$ & $\mathrm{V}$ \\
\hline KR080142 & farm B_3 & $\mathrm{Y}$ & $\mathrm{T}$ & $\mathrm{G}$ & - & $\mathrm{Q}$ & $\mathrm{E}$ & $\mathrm{T}$ & $\mathrm{G}$ & $\mathrm{T}$ & $\mathrm{K}$ & $\mathrm{T}$ & $\mathrm{S}$ & . & $\mathrm{L}$ & . & I & . & $\mathrm{E}$ & $\mathbf{H}$ & . & $\mathrm{V}$ \\
\hline KR080143 & farm B_4 & $\mathrm{Y}$ & $\mathrm{M}$ & G & $\mathrm{Q}$ & $\mathrm{Q}$ & $\mathrm{E}$ & $\mathrm{T}$ & $\mathrm{G}$ & $\mathrm{T}$ & $\mathrm{K}$ & $\mathrm{T}$ & $\mathrm{S}$ & $\mathrm{R}$ & $\mathrm{L}$ & . & $\mathrm{I}$ & $\mathrm{L}$ & $\mathrm{E}$ & $\mathbf{H}$ & . & $\mathrm{V}$ \\
\hline KR080144 & farm B_5 & $\mathrm{Y}$ & $\mathrm{T}$ & $\mathrm{G}$ & - & $\mathrm{Q}$ & $\mathrm{E}$ & $\mathrm{T}$ & $\mathrm{G}$ & $\mathrm{T}$ & $\mathrm{K}$ & $\mathrm{T}$ & $\mathrm{S}$ & $\mathrm{A}$ & $\mathrm{L}$ &. & $\mathrm{I}$ &. & $\mathrm{E}$ & $\mathbf{H}$ &. & $\mathrm{V}$ \\
\hline KR080136 & farm A_1 &. & $\mathrm{T}$ & $\mathrm{G}$ & $\mathrm{Q}$ & $\mathrm{Q}$ & $E$ & I & $\mathrm{G}$ & $\mathrm{T}$ & $\mathrm{K}$ & $\mathrm{T}$ & $\mathrm{S}$ & $\mathrm{K}$ & $\mathrm{L}$ & . &. & $\mathrm{V}$ & . &. & $\mathrm{K}$ & $\mathrm{V}$ \\
\hline KR080137 & farm A_2 & . & $\mathrm{T}$ & G & $\mathrm{Q}$ & $\mathrm{Q}$ & $\mathrm{E}$ & $\mathrm{T}$ & G & $\mathrm{T}$ & $\mathrm{K}$ & $\mathrm{T}$ & $\mathrm{S}$ & $\mathrm{R}$ & $\mathrm{L}$ & . & . & $\mathrm{V}$ & . & . & . & $\mathrm{V}$ \\
\hline KR080138 & farm A_3 &. & $\mathrm{T}$ & $\mathrm{G}$ & $\mathrm{Q}$ & $\mathrm{Q}$ & $\mathrm{E}$ & $\mathrm{T}$ & $\mathrm{G}$ & $\mathrm{T}$ & $\mathrm{K}$ & $\mathrm{T}$ & $S$ & $\mathrm{~A}$ & $\mathrm{~L}$ &. &. & $\mathrm{~V}$ &. & . & . & $\mathrm{V}$ \\
\hline KR080139 & farm A_4 & . & $\mathrm{T}$ & $\mathrm{G}$ & $\mathrm{Q}$ & $\mathrm{Q}$ & $\mathrm{E}$ & $\mathrm{T}$ & $\mathrm{G}$ & $\mathrm{T}$ & $\mathrm{K}$ & $\mathrm{T}$ & $\mathrm{S}$ & $\mathrm{K}$ & $\mathrm{L}$ &. & . & $\mathrm{V}$ & . & . &. & $\mathrm{V}$ \\
\hline KJ174161.1 & Belarus & $\mathrm{Y}$ & $\mathrm{M}$ & G & $\mathrm{Q}$ & $\mathrm{Q}$ & $\mathrm{E}$ & $\mathrm{T}$ & $\mathrm{G}$ & $\mathrm{T}$ & $\mathrm{K}$ & . & . & . & $\mathrm{L}$ &. & $\mathrm{I}$ & $\mathrm{V}$ & $\mathrm{E}$ & . & . & $\mathrm{V}$ \\
\hline KJ174163.1 & Belarus &. & . & . &. & . & . & . &. & . &. &. & . & . &. &. &. &. &. & . &. & $\mathrm{V}$ \\
\hline EU652449.1 & China & . & $S$ & . & $\mathrm{Q}$ & $\mathrm{Q}$ & $\mathrm{E}$ & $\mathrm{T}$ & $\mathrm{G}$ & $\mathrm{T}$ & $\mathrm{K}$ & $\mathrm{R}$ & . & $\mathrm{A}$ & $\mathrm{L}$ & . & . & . & $E$ & . & . & $\mathrm{V}$ \\
\hline EU652450.1 & China &. & $\mathrm{L}$ & $\mathrm{G}$ & $\mathrm{Q}$ & $\mathrm{Q}$ & $\mathrm{E}$ & $\mathrm{T}$ & G & $\mathrm{T}$ & $\mathrm{K}$ & . & . & . & $\mathrm{L}$ & . & . & . & $\mathrm{D}$ & . & . & $\mathrm{V}$ \\
\hline EU652451.1 & China &. & $\mathrm{M}$ & $\mathrm{G}$ & $\mathrm{Q}$ & $\mathrm{Q}$ & $\mathrm{E}$ & $\mathrm{T}$ & $\mathrm{G}$ & $\mathrm{T}$ & $\mathrm{K}$ &. & . & . &. &. &. &. &. & . & . & $\mathrm{V}$ \\
\hline EU652452.1 & China & . & $\mathrm{T}$ & $\mathrm{G}$ & - & $\mathrm{Q}$ & $\mathrm{E}$ & $\mathrm{T}$ & $\mathrm{G}$ & $\mathrm{T}$ & $\mathrm{K}$ & . & . & $\mathrm{K}$ & $\mathrm{L}$ & . & . & . & $E$ & . & . & $\mathrm{V}$ \\
\hline GU183264.1 & China & $\mathrm{Y}$ & $\mathrm{S}$ & $\mathrm{G}$ & $\mathrm{Q}$ & $\mathrm{Q}$ & $\mathrm{E}$ & $\mathrm{T}$ & G & $\mathrm{T}$ & $\mathrm{K}$ & . & . & $\mathrm{V}$ & . & . & . & . & . & . & . & $\mathrm{V}$ \\
\hline GU183265.1 & China & . & $\mathrm{T}$ & $\mathrm{G}$ & $\mathrm{Q}$ & $\mathrm{Q}$ & $\mathrm{E}$ & $\mathrm{T}$ & G & $\mathrm{T}$ & $\mathrm{K}$ & . & . & $\mathrm{V}$ & $\mathrm{L}$ & $\mathrm{Q}$ & . & . & $\mathrm{E}$ & . & . & $\mathrm{V}$ \\
\hline GU269892.1 & China & $\mathrm{Y}$ & $\mathrm{S}$ & $\mathrm{G}$ & $\mathrm{Q}$ & $\mathrm{Q}$ & $\mathrm{E}$ & $\mathrm{T}$ & $\mathrm{G}$ & $\mathrm{T}$ & . &. & . & . & . & . & . & . & $E$ & . &. & $\mathrm{V}$ \\
\hline EU652446.1 & China & . & $\mathrm{T}$ & G & $\mathrm{A}$ & - & $\mathrm{E}$ & $\mathrm{T}$ & G & $\mathrm{T}$ & $\mathrm{K}$ & $\mathrm{T}$ & $\mathrm{S}$ & . & $\mathrm{L}$ & . & . & $\mathrm{V}$ & . & . & . & $\mathrm{V}$ \\
\hline EU652447.1 & China & . & $\mathrm{T}$ & G & - & $\mathrm{Q}$ & $\mathrm{E}$ & $\mathrm{T}$ & G & $\mathrm{T}$ & $\mathrm{K}$ & . & . & $\mathrm{K}$ & $\mathrm{L}$ &. & . & . & $\mathrm{E}$ & . & . & $\mathrm{V}$ \\
\hline EU652448.1 & China & . & $\mathrm{M}$ & $\mathrm{G}$ & $\mathrm{Q}$ & $\mathrm{Q}$ & $E$ & $\mathrm{~T}$ & $\mathrm{G}$ & $\mathrm{T}$ & $\mathrm{K}$ & . & . & . & . &. & . & . & . & . & . & $\mathrm{V}$ \\
\hline GQ336866.1 & Finland & . & . & $\mathrm{S}$ & & . & . & . & . & . & . & . & . & $\mathrm{A}$ & . & . & . & . & . & . & . & $\mathrm{V}$ \\
\hline DQ630715.1 & Ireland & $\mathrm{Y}$ & $\mathrm{T}$ & G & $\mathrm{Q}$ & $\mathrm{Q}$ & $\mathrm{E}$ & $\mathrm{T}$ & G & $\mathrm{T}$ & $\mathrm{K}$ & . & $\mathrm{S}$ & $\mathrm{A}$ & $\mathrm{L}$ & . & . & . & $\mathrm{E}$ & . & . & $\mathrm{V}$ \\
\hline DQ630716.1 & Ireland & $\mathrm{Y}$ & $\mathrm{M}$ & $\mathrm{G}$ & $\mathrm{Q}$ & $\mathrm{Q}$ & $\mathrm{E}$ & $\mathrm{T}$ & $\mathrm{G}$ & $\mathrm{T}$ & $\mathrm{K}$ & $\mathrm{T}$ & $\mathrm{S}$ & $\mathrm{A}$ & $\mathrm{L}$ & $\mathrm{Q}$ & . & $\mathrm{V}$ & . & . & . & $\mathrm{V}$ \\
\hline DQ630717.1 & Ireland & $\mathrm{Y}$ & $\mathrm{M}$ & $\mathrm{G}$ & $\mathrm{Q}$ & $\mathrm{Q}$ & $\mathrm{E}$ & $\mathrm{T}$ & $\mathrm{G}$ & $\mathrm{T}$ & $\mathrm{K}$ & $\mathrm{T}$ & $\mathrm{S}$ & $\mathrm{A}$ & $\mathrm{L}$ & . & $\mathrm{I}$ & $\mathrm{V}$ & . & . & . & $\mathrm{V}$ \\
\hline DQ630718.1 & Ireland & . & . & . & . & . & . &. &. &. & $\mathrm{K}$ & . & . & $\mathrm{R}$ & $\mathrm{L}$ &. &. & . & $\mathrm{E}$ & . & . & $\mathrm{V}$ \\
\hline DQ630719.1 & Ireland & . & $\mathrm{S}$ & . & $\mathrm{Q}$ & $\mathrm{Q}$ & $E$ & $\mathrm{~T}$ & . & $\mathrm{T}$ & $\mathrm{K}$ & $\mathrm{T}$ & $\mathrm{S}$ & $\mathrm{K}$ & $\mathrm{L}$ & . & $\mathrm{I}$ & $\mathrm{V}$ & $E$ & . &. & $\mathrm{V}$ \\
\hline DQ630721.1 & Ireland & . & $\mathrm{S}$ & & $\mathrm{Q}$ & $\mathrm{Q}$ & $\mathrm{E}$ & $\mathrm{T}$ & . & $\mathrm{T}$ & $\mathrm{K}$ & $\mathrm{T}$ & $\mathrm{S}$ & . & $\mathrm{L}$ & . & $\mathrm{I}$ & $\mathrm{V}$ & . & . & . & $\mathrm{V}$ \\
\hline DQ630722.1 & Ireland & . & $\mathrm{S}$ & & $\mathrm{Q}$ & $\mathrm{Q}$ & $\mathrm{E}$ & $\mathrm{T}$ & G & $\mathrm{T}$ & $\mathrm{K}$ & 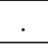 & . & $\mathrm{A}$ & $\mathrm{L}$ & $\mathrm{D}$ & $\mathrm{I}$ & . & $\mathrm{E}$ &. & . & $\mathrm{V}$ \\
\hline DQ630723.1 & Ireland &. & $\mathrm{S}$ & . & $\mathrm{Q}$ & $\mathrm{Q}$ & $E$ & $\mathrm{~T}$ & $\mathrm{G}$ & $\mathrm{T}$ & $\mathrm{K}$ &. & . & $\mathrm{A}$ & $\mathrm{L}$ & . &. & . & $E$ & . &. & $\mathrm{V}$ \\
\hline DQ630724.1 & Ireland & . & $\mathrm{M}$ & . & $\mathrm{Q}$ & $\mathrm{Q}$ & $\mathrm{E}$ & $\mathrm{T}$ & G & $\mathrm{T}$ & $\mathrm{K}$ & $\mathrm{T}$ & . & . & $\mathrm{L}$ & . & $\mathrm{I}$ & $\mathrm{V}$ & . & . & . & $\mathrm{V}$ \\
\hline KM494944.1 & Canada & . &. & $\mathrm{P}$ & $\mathrm{S}$ & . & . & . & . &. & . & . & . & $\mathrm{V}$ & . & . & . & . & . & . & . & $\mathrm{V}$ \\
\hline KM494945.1 & Canada &. &. & $\mathrm{S}$ & $\mathrm{S}$ & . &. &. & . & . &. &. & . & $\mathrm{V}$ & . & . & . & . & . & . &. & $\mathrm{V}$ \\
\hline X97629.1 & Germany & . & . & . & & . & . & . & . & . & . & . & . & . & . & . & . & . & . & . & . & . \\
\hline DQ371395.1 & Russia & . & $\mathrm{T}$ & G & $\mathrm{Q}$ & - & $\mathrm{E}$ & $\mathrm{T}$ & $\mathrm{G}$ & $\mathrm{T}$ & $\mathrm{K}$ & . & . & $\mathrm{K}$ & . & . & . & . & . & 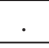 & . & . \\
\hline KJ174158.1 & Russia & . & . & . & . & . & . & . & . & . & . & . & . & A & . & . & . & . & . & . & . & $\mathrm{V}$ \\
\hline KJ174159.1 & Russia & . & . & . & & . & $\mathrm{I}$ & . & . & . & . & . & . & . &. & . & . & . & . & . & . & $\mathrm{V}$ \\
\hline KJ174160.1 & Russia & . & . & 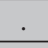 & & . & . & . & . & . & . & . & . & . & . & $\mathrm{D}$ & . & . & . & 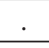 & . & $\mathrm{V}$ \\
\hline KJ174162.1 & Russia & . &. & . &. &. &. &. & . & . &. &. & . & . &. &. & . & . & . & . & . & $\mathrm{V}$ \\
\hline KJ174164.1 & Russia & . & $\mathrm{T}$ & G & - & $\mathrm{Q}$ & $\mathrm{E}$ & $\mathrm{T}$ & G & $\mathrm{T}$ & $\mathrm{K}$ & . & . & A & $\mathrm{L}$ & . & . & . & . & . & . & $\mathrm{V}$ \\
\hline AF124791.1 & USA & . & . & & G & 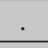 & . & . & . & . & - & . & . & . & . & . & . & . & . & 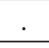 & . & $\mathrm{V}$ \\
\hline M32981.1 & USA & . & $\mathrm{L}$ & $\mathrm{G}$ & $\mathrm{Q}$ & $\mathrm{Q}$ & $\mathrm{E}$ & $\mathrm{T}$ & $\mathrm{G}$ & $\mathrm{T}$ &. &. & . & . &. &. & . & . & . & . & . & $\mathrm{V}$ \\
\hline U39013.1 & USA & . & . & & & . & . & . & . & . & $\mathrm{K}$ & . & . & . & . & . & . & . & $\mathrm{E}$ & . & . & $\mathrm{V}$ \\
\hline U39014.1 & USA & $\mathrm{Y}$ & $\mathrm{A}$ & & $\mathrm{Q}$ & $\mathrm{P}$ & $\mathrm{E}$ & $\mathrm{T}$ & G & $\mathrm{T}$ & $\mathrm{K}$ & . & . & $\mathrm{V}$ & $\mathrm{L}$ & . & $\mathrm{I}$ & $\mathrm{T}$ & $\mathrm{E}$ & & . & $\mathrm{V}$ \\
\hline U39015.1 & USA & . & $\mathrm{M}$ & $\mathrm{G}$ & $\mathrm{Q}$ & $\mathrm{Q}$ & $E$ & $\mathrm{~T}$ & $\mathrm{G}$ & $\mathrm{T}$ &. & 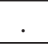 & . & . & . &. & . & . & . & 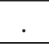 & . & $\mathrm{V}$ \\
\hline
\end{tabular}

$\left(^{*}\right)$ grey indicates the hypervariable region, $\left.{ }^{(*}\right)=$ letters in bold indicate variants previously unnoted in the VP2 region in the NCBI database. 


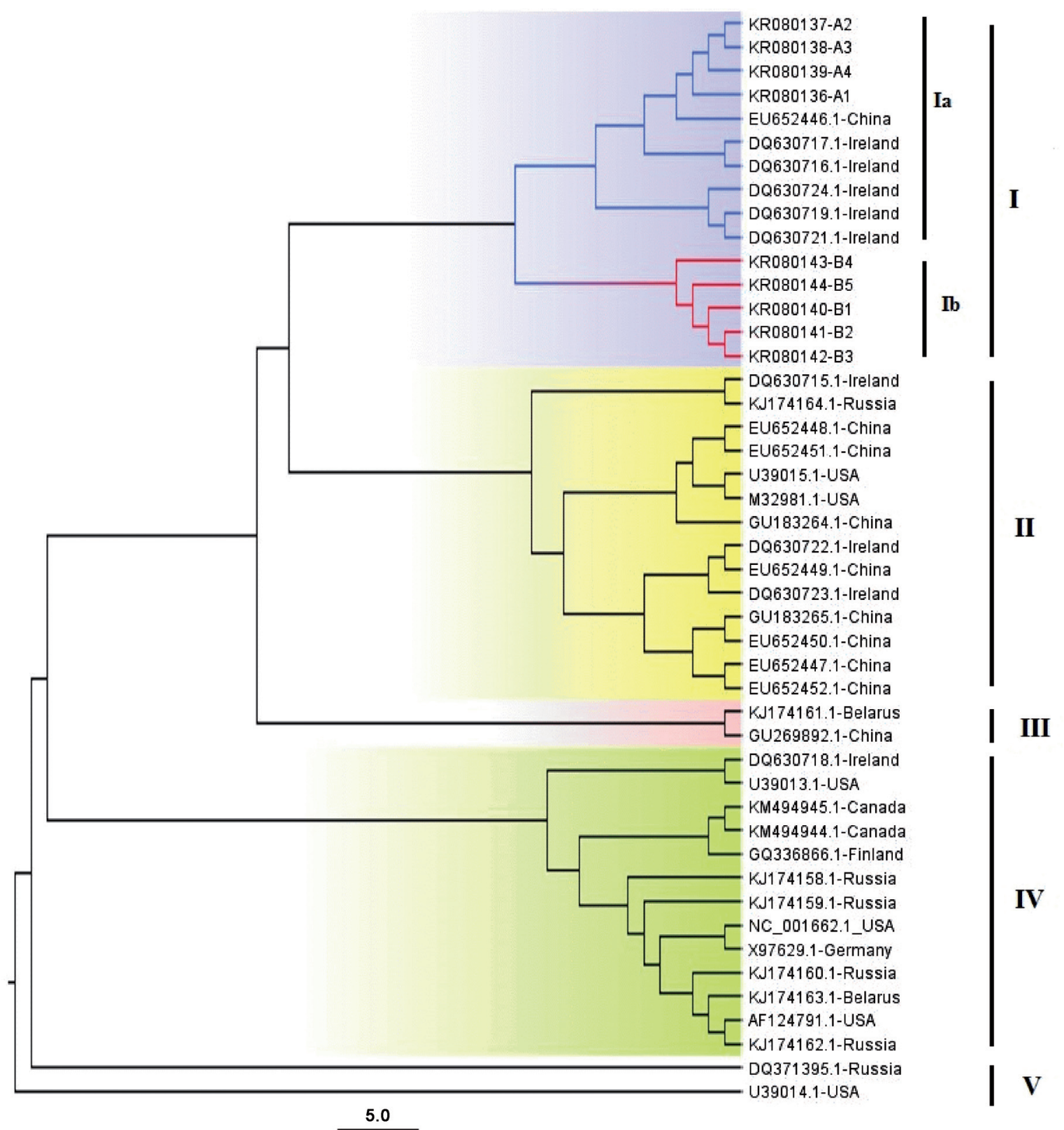

Fig. 1

Phylogenetic relatedness between Polish variants of AMDV and strains isolated abroad

Phylogenetic tree based on alignment of the fragment (203 amino acids) of the AMDV VP2 protein. The tree was constructed with MEGA 6 using UPGMA method. The strains fell into five groups, designated by numbers I, II, III, IV and V. The scale of genetic distance is reflected by the scale bar provided below.

these changes were located near the hypervariable region. In the present study, a $\mathrm{N} 332 \mathrm{H}$ substitution in the region lying outside the hypervariable region in the isolates from farm $B$ appears to be a good marker of origin.

Isolates from both farms are found within a common main clade (group I), but occupy two different branches of it (Ia and Ib). The sequenced strains share the same clade with Irish isolates [GenBank: DQ630716.1, DQ630717.1, DQ630724.1] and a Chinese strain - LFB783 [GenBank: EU652446.1], while in the case of isolates from geographically closer locations such as Belarus, the phylogenetic distance to the isolates from Poland is greater. The diversity between the isolates obtained suggests that AMDV has been introduced to Poland at least twice. It is possible that isolates 
from Poland may have a common ancestor with strains from group II, which are considered the most devastating. This group is represented by highly virulent strains such as the Utah strain [GenBank: M32981.1], isolated in the early 1960s. This clade also contains such strains as LN1 and LN2, described by Li et al. (2012).

Group IV includes the non-pathogenic strain AMDV-G, as well as the intermediately virulent ADV-SL3 [GenBank: X97629.1]. According to Jahns et al. (2010), the strains belonging to this group are very closely related to the nonpathogenic strain. Wang et al. (2014) include a strain from Finland, AMDV-FIN [GenBank: GQ336866.1], in the same group.

Evolution of AMDV strains towards lesser virulence may have adaptive value by facilitating persistence and spread among hosts. High pathogenicity may result in high mortality of hosts, which then cannot infect other individuals. This hypothesis is confirmed both by high seroprevalence in populations of wild minks (Farid et al., 2010, 2012; Farid, 2013) and breeding minks (Sang et al., 2012; Wang et al., 2014) and by detection of AMDV antibodies in carnivores such as martens, polecats (Fournier-Chambrillon et al., 2004) and raccoons, which can be alternative hosts and reservoirs of AMDV (Nituch et al., 2015).

We come to a similar conclusion as Wang et al. (2014), i.e. that isolates from Poland mutate towards reduced virulence with respect to their more virulent ancestors. This seems to be confirmed by the pathogen's relatively low rate of spread and low mortality rate.

Conclusions. The results of our study confirm great variability in the VP2 sequence between different isolates of AMDV. The fact that variants were obtained that had not previously been reported suggests the need for further analyzes leading to the identification of other genetic variants of AMDV and a better understanding of the link between amino acid sequence polymorphism and pathogenicity. Precise knowledge of genetic variants of the virus can be used to develop even more precise molecular tests, which will make it possible to limit the spread of AMDV. This may be of particular significance in purchasing animals for breeding and in preventing AMDV infections. Moreover, the high degree of variation in variants of the virus can be useful in identifying the sources of infection through the use of phylogenetic analyses of the pathogen.

Acknowledgements. This project has been funded by Polish National Science Centre (project N N308 599939).

\section{References}

Andersson A-M, Wallgren P (2013): Evaluation of two enzymelinked immunosorbent assays for serodiagnosis of Aleutian mink disease virus infection in mink. Acta Vet. Scand. 55, 86. https:/doi.org/10.1186/1751-0147-55-86
Battilani M, Scagliarini A, Ciulli S, Morganti L, Prosperi S (2006): High genetic diversity of the VP2 gene of a canine parvovirus strain detected in a domestic cat. Virology 352, 22-26. https:/doi.org/10.1016/j. virol.2006.06.002

Bloom ME, Best SM, Hayes SF, Wells RD, Wolfinbarger JB, McKenna R, Agbandje-McKenna M (2001): Identification of Aleutian mink disease parvovirus capsid sequences mediating antibody-dependent enhancement of infection, virus neutralization, and immune complex formation. J. Virol. 75, 11116-11127. https:/doi.org/10.1128/ IVI.75.22.11116-11127.2001

Christensen LS, Gram-Hansen L, Chriel M, Jensen TH (2011): Diversity and stability of Aleutian mink disease virus during bottleneck transitions resulting from eradication in domestic mink in Denmark. Vet. Microbiol. 149, 64-71. https:/doi.org/10.1016/j.vetmic.2010.10.016

Costello F, Steenfos N, Jensen KT, Christensen J, Gottschalck E, Holm A, Aasted B (1999): Epitope mapping of Aleutian Mink Disease Parvovirus virion protein VP1 and 2. Scand. J. Immunol. 49, 347-354. https:/doi.org/10.1046/j.13653083.1999.00499.x

Dam-Tuxen R, Dahl J, Jensen TH, Dam-Tuxen T, Struve T, Bruun L (2014): Diagnosing Aleutian mink disease infection by a new fully automated ELISA or by counter current immunoelectrophoresis: A comparison of sensitivity and specificity. J. Virol. Methods 199, 53-60. https:/doi. org/10.1016/j.jviromet.2014.01.011

Farid AH (2013): Aleutian mink disease virus in furbearing mammals in Nova Scotia, Canada. Acta Vet. Scand. 55, 10. https:/doi.org/10.1186/1751-0147-55-10

Farid AH, Rupasinghe P, Mitchell JL, Rouvinen-Watt K (2010): A survey of Aleutian mink disease virus infection of feral American mink in Nova Scotia. Can. Vet. J. 51, 75-77.

Farid AH, Zillig ML, Finley GG, Smith GC (2012): Prevalence of the Aleutian mink disease virus infection in Nova Scotia, Canada. Prev. Vet. Med. 106, 332-338. https:/doi. org/10.1016/j.prevetmed.2012.03.010

Fournier-Chambrillon C, Aasted B, Perrot A, Pontier D, Sauvage $\mathrm{F}$, Artois $\mathrm{M}$, Cassiede JM, Chauby X, Dal Molin A, Simon C, Fournier P (2004): Antibodies to aleutian mink disease parvovirus in free-ranging European mink (Mustela lutreola) and other small carnivores from Southwestern France. J. Wildl Dis. 40, 394-402. https:/ doi.org/10.7589/0090-3558-40.3.394

Gottschalck E, Alexandersen S, Cohn A, Poulsen LA, Bloom ME, Aasted B (1991): Nucleotide sequence analysis of Aleutian mink disease parvovirus shows that multiple virus types are present in infected mink. J. Virol. 65, 4378-4386.

Huang Q, Luo Y, Cheng F, Best SM, Bloom ME, Qiu J (2014): Molecular characterization of the small nonstructural proteins of parvovirus Aleutian mink disease virus (AMDV) during infection. Virology 452, 23-31. https:/ doi.org/10.1016/j.virol.2014.01.005

Jahns H, Daly P, McElroy MC, Sammin DJ, Bassett HF, Callanan JJ (2010): Neuropathologic features of Aleutian disease in farmed mink in Ireland and molecular characterization of Aleutian mink disease virus detected in brain 
tissues. J. Vet. Diag. Invest. 22, 101-105. https:/doi. org/10.1177/104063871002200120

Knuuttila A, Aronen P, Saarinen A, Vapalahti O (2009a): Development and Evaluation of an Enzyme-Linked Immunosorbent Assay Based on Recombinant VP2 Capsids for the Detection of Antibodies to Aleutian Mink Disease Virus. Clin. Vaccine Immunol. 16, 1360-1365. https:/doi. org/10.1128/CVI.00148-09

Knuuttila A, Uzcategui N, Kankkonen J, Vapalahti O, Kinnunen P (2009b): Molecular epidemiology of Aleutian mink disease virus in Finland. Vet. Microbiol. 133, 229-238. https:/doi.org/10.1016/j.vetmic.2008.07.003

Leimann A, Knuuttila A, Maran T, Vapalahti O, Saarma U (2015): Molecular epidemiology of Aleutian mink disease virus (AMDV) in Estonia, and a global phylogeny of AMDV. Virus Res. 199, 56-61. https:/doi.org/10.1016/j. virusres.2015.01.011

Li Y, Huang J, Jia Y, Du Y, Jiang P, Zhang R (2012): Genetic characterization of Aleutian mink disease viruses isolated in China. Virus Genes 45, 24-30. https:/doi.org/10.1007/ $\underline{\text { s11262-012-0733-X }}$

Majer-Dziedzic B, Jakubczak A, Zietek J (2011): Phylogenetic analysis of canine parvovirus CPV-2 strains and its variants isolated in Poland. Pol. J. Vet. Sci. 14, 379-384. https:/ doi.org/10.2478/v10181-011-0057-0

McKenna R, Olson NH, Chipman PR, Baker TS, Booth TF, Christensen J, Aasted B, Fox JM, Bloom ME, Wolfinbarger JB, Agbandje-McKenna M (1999): Three-dimensional structure of Aleutian mink disease parvovirus: Implications for disease pathogenicity. J. Virol. 73, 6882-6891.

Nituch LA, Bowman J, Wilson PJ, Schulte-Hostedde AI (2015): Aleutian mink disease virus in striped skunks (Mephitis mephitis): evidence for cross-species spillover. J. Wildl Dis. 51, 389-400. https:/doi.org/10.7589/2014-05-141

Oie KL, Durrant G, Wolfinbarger JB, Martin D, Costello F, Perryman S, Hogan D, Hadlow WJ, Bloom ME (1996): Relationship between capsid protein (VP2) sequence and pathogenicity of Aleutian mink disease parvovirus (ADV): A possible role for raccoons in the transmission of ADV infections. J. Virol. 70, 852-861.

Olofsson A, Mittelholzer C, Berndtsson LT, Lind L, Mejerland T, Belak S (1999): Unusual, high genetic diversity of
Aleutian mink disease virus. J. Clin. Microbiol. 37, 4145-4149.

Pennick KE, Stevenson MAM, Latimer KS, Ritchie BW, Gregory CR (2005): Persistent viral shedding during asymptomatic Aleutian mink disease parvoviral infection in a ferret. J. Vet. Diagn. Invest. 17, 594-597. https:/doi. org/10.1177/104063870501700614

Persson S, Jensen TH, Blomstrom A-L, Appelberg MT, Magnusson U (2015): Aleutian mink disease virus in free-ranging mink from sweden. PloS one 10, e0122194-e0122194. https:/doi.org/10.1371/journal.pone.0122194

Qiu JM, Cheng F, Burger LR, Pintel D (2006): The transcription profile of Aleutian mink disease virus in CRFK cells is generated by alternative processing of Pre-mRNAs produced from a single promoter. J. Virol. 80, 654-662. https:/doi.org/10.1128/JVI.80.2.654-662.2006

Reichert M, Kostro K (2014a): Effect of persistent infection of mink with Aleutian mink disease virus on reproductive failure. Bull. Vet. Inst. Pulawy 58, 369-373. https:/doi. org/10.2478/bvip-2014-0057

Reichert M, Kostro K (2014b): NS1 gene based molecular characteristics of Aleutian mink disease virus circulating in Poland. Bull. Vet. Inst. Pulawy 58, 187-191. https:/doi. org/10.2478/bvip-2014-0028

Sanchez-Migallon Guzman D, Carvajal A, Garcia-Marin JF, Ferreras MC, Perez V, Mitchell M, Urra F, Cena JC (2008): Aleutian disease serology, protein electrophoresis, and pathology of the European mink (Mustela lutreola) from Navarra, Spain. J. Zoo Wildlife Med. 39, 305-13. https:/ doi.org/10.1638/2006-0033.1

Sang Y, Ma J, Hou Z, Zhang Y (2012): Phylogenetic analysis of the VP2 gene of Aleutian mink disease parvoviruses isolated from 2009 to 2011 in China. Virus Genes 45, 31-37. https:/doi.org/10.1007/s11262-012-0734-9

Shackelton LA, Parrish CR, Truyen U, Holmes EC (2005): High rate of viral evolution associated with the emergence of carnivore parvovirus. Proc. Natl. Acad. Sci. USA 102, 379-384. https:/doi.org/10.1073/pnas.0406765102

Wang Z, Wu W, Hu B, Zhang H, Bai X, Zhao J, Zhang L, Yan X (2014): Molecular epidemiology of Aleutian mink disease virus in China. Virus Res. 184, 14-19. https:/doi. org/10.1016/j.virusres.2014.02.007 